Article

\title{
Tracing the Lineage of Two Traits Associated with the Coat Protein of the Tombusviridae: Silencing Suppression and HR Elicitation in Nicotiana Species
}

\author{
Mustafa Adhab ${ }^{1,2}{ }^{2}$, Carlos Angel ${ }^{3}$, Andres Rodriguez ${ }^{1}$, Mohammad Fereidouni ${ }^{1}$, Lóránt Király ${ }^{4}$, \\ Kay Scheets ${ }^{5}$ and James E. Schoelz ${ }^{1, *}$ \\ 1 Division of Plant Sciences, University of Missouri, Columbia, MO 65211, USA \\ 2 Department of Plant Protection, University of Baghdad, 10071 Baghdad, Iraq \\ 3 National Coffee Research Center-Cenicafe, Planalto, km. 4, Vía antigua Chinchiná-Manizales, \\ Manizales (Caldes), Colombia \\ 4 Department of Pathophysiology, Plant Protection Institute, Centre for Agricultural Research, Hungarian \\ Academy of Sciences, H-1022 Budapest, Herman Ottó str. 15, Hungary \\ 5 Department of Plant Biology, Ecology, and Evolution, Oklahoma State University, Stillwater, OK 74078, USA \\ * Correspondence: schoelzj@missouri.edu; Tel.: +01-573-882-185
}

Received: 18 April 2019; Accepted: 20 June 2019; Published: 28 June 2019

\begin{abstract}
In this paper we have characterized the lineage of two traits associated with the coat proteins (CPs) of the tombusvirids: Silencing suppression and HR elicitation in Nicotiana species. We considered that the tombusvirid CPs might collectively be considered an effector, with the CP of each CP-encoding species comprising a structural variant within the family. Thus, a phylogenetic analysis of the $\mathrm{CP}$ could provide insight into the evolution of a pathogen effector. The phylogeny of the $\mathrm{CP}$ of tombusvirids indicated that $\mathrm{CP}$ representatives of the family could be divided into four clades. In two separate clades the CP triggered a hypersensitive response (HR) in Nicotiana species of section Alatae but did not have silencing suppressor activity. In a third clade the $\mathrm{CP}$ had a silencing suppressor activity but did not have the capacity to trigger HR in Nicotiana species. In the fourth clade, the $\mathrm{CP}$ did not carry either function. Our analysis illustrates how structural changes that likely occurred in the $\mathrm{CP}$ effector of progenitors of the current genera led to either silencing suppressor activity, HR elicitation in select Nicotiana species, or neither trait.
\end{abstract}

Keywords: virus effectors; host resistance; hypersensitive response; virus silencing suppressors; avirulence; tombusvirids

\section{Introduction}

Plant defenses against viral pathogens may be divided into two broad categories. The first line of defense in plants involves their capacity to recognize viral nucleic acids, typically double stranded RNAs, and to mobilize the gene silencing machinery to target the viral RNAs for degradation [1,2]. This defense response is known as RNA silencing (or RNAi), and several recent reviews have noted the similarity of the RNAi defense against viruses to Pathogen-Associated Molecular Pattern (PAMP)-Triggered Immunity (PTI), which has been characterized for bacterial, fungal and oomycete pathogens [3-5]. Indeed, modifications of the zigzag model for evolution of innate immunity have been proposed that equate the RNAi response against viral pathogens to the PAMP response against nonviral pathogens $[3,5]$. Most or perhaps all plant viruses encode one or more proteins in their genome to suppress the effects of RNAi and protect their genomic RNA from degradation before it is encapsidated into virions [1,2]. 
A second line of defense in plants involves the capacity to recognize specific virus proteins by host resistance $(\mathrm{R})$ proteins, which frequently leads to the development of a hypersensitive response (HR) [3-7]. HR against virus infections is typically manifested through the development of necrotic local lesions that may appear as early as two days post-inoculation (dpi) or up to $7 \mathrm{dpi}$, depending on the host/virus combination. Virus proteins recognized in this manner by host resistance proteins fit the definition of avirulence (avr) proteins in accordance with the gene-for-gene theory [3-6].

In this paper we have characterized the lineage of two traits associated with the coat proteins (CPs) of the tombusvirids: Silencing suppression and avirulence. Such an analysis could be valuable for understanding the interplay between plant defense elicitation and counterdefense functions associated with a pathogen effector. Members of the Tombusviridae are characterized by ssRNA genomes individually encapsidated into icosahedral virions. The family currently consists of 76 species, with the majority distributed within 16 genera. One genus, umbravirus, is unusual in that the viruses in this genus do not encode a $\mathrm{CP}$, relying instead on the $\mathrm{CP}$ of their specific helper viruses [8].

Analyses of the gene order and proteins encoded by different tombusvirids indicates that one of the mechanisms that has given rise to new genera is recombination between species from different genera REFs [9-12]. Thus, genera are now defined based on the phylogenies of the complete RNA dependent RNA polymerase (RdRP) and the number of sgRNAs produced, which led to the division of genus Carmovirus into three new genera [9], while genus Necrovirus was split into Alphanecrovirus and Betanecrovirus [11] the RdRPs of alphanecroviruses and betanecroviruses lie on separate branches of RdRP phylogenetic trees, and do not reproduce the relationship of their CPs.

Several studies have shown that the CPs of this diverse family have the capacity to trigger HR in some of their hosts and/or may function as silencing suppressors. For example, the CP of the betacarmovirus turnip crinkle virus (TCV) elicits HR in Arabidopsis thaliana ecotype Dijon $[13,14]$ and also functions as a silencing suppressor [15-17], although CP motifs conditioning silencing suppressor activity can be uncoupled from HR elicitation [18,19]. In addition to TCV, the CPs of alphacarmoviruses, gammacarmoviruses and pelarspoviruses have also been demonstrated to have silencing suppressor activity [20-23]. The CP of the tombusvirus tomato bushy stunt virus (TBSV) triggers HR in six species of Nicotiana belonging to section Alatae [24] and is not a silencing suppressor [15]. However, most tombusvirid CPs have not been evaluated for the capacity to elicit HR in Nicotiana species and some have not been evaluated for silencing suppression. Nonetheless, tombusvirid CPs might collectively be considered an effector, with the $\mathrm{CP}$ of each species comprising a structural variant within the dataset. Thus, a phylogenetic analysis of the CPs could provide insight into the evolution of a pathogen effector/avr protein.

To initially explore the avr potential of tombusvirid CPs, we focused on the capacity of the $\mathrm{CP}$ of tobacco necrosis virus strain $\mathrm{D}$, isolate Hungary (abbreviated here as $\mathrm{TNVD}^{\mathrm{H}}$ ), to trigger $\mathrm{HR}$ in Nicotiana species. TNVD ${ }^{\mathrm{H}}$ belongs is a betanecrovirus; its genome consists of a positive-sense, single-stranded RNA of approximately $3.8 \mathrm{~kb}$ that is encapsidated into small icosahedral viral particles with a diameter of 28 nanometers [25,26]. The genome of $\mathrm{TNVD}^{\mathrm{H}}$ encodes five proteins that are expressed through a combination of readthrough strategies and subgenomic RNAs (Figure 1A) [27]. The P22 and the readthrough product P82 are necessary for replication, the P7a and P7b proteins are necessary for movement, and the P29 protein is the coat protein, responsible for formation of the icosahedral particles [26,28]. TNVD has been transmitted experimentally to at least 88 species in 37 dicotyledonous and monocotyledonous families and it elicits HR in the majority of these species [29]. The only hosts that were initially shown to be systemically infected by TNV were Anthriscus cerefolium and Trachymene cerulea [29]. It has recently been shown that TNV also induces a systemic necrosis in Nicotiana benthamiana [26] and a symptomless infection in Arabidopsis thaliana [30]. 


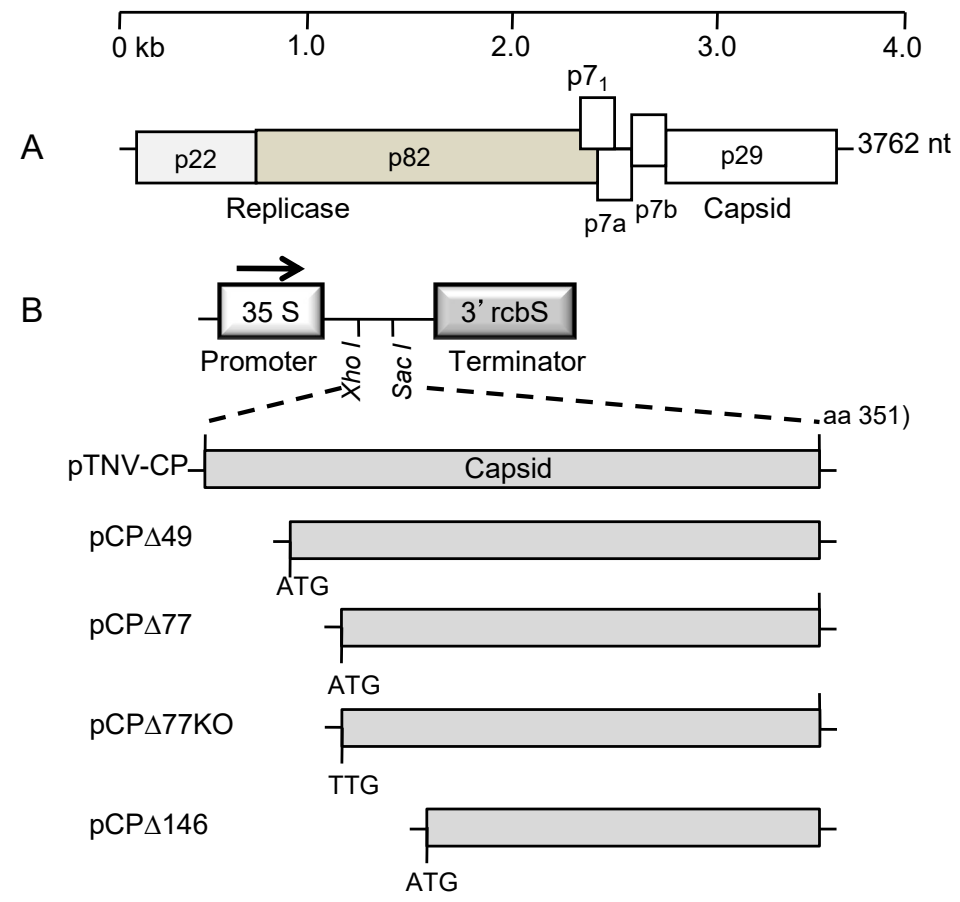

Figure 1. Genome organization of $\mathrm{TNVD}^{\mathrm{H}}$, and TNV CP constructs used for transient expression in Nicotiana species. (A) TNV-D ${ }^{\mathrm{H}}$ genome structure. The six open reading frames are illustrated by boxes. The $\mathrm{p} 82$ protein is highlighted in a different color from the $\mathrm{p} 22$ protein to emphasize that it is a readthrough product of the p22 protein. (B) Structure of inserts into the Agrobacterium binary vector pKYLX7. The arrow indicates the direction of transcription of the 35S promoter. All TNV CP constructs were generated by PCR and delimited by XhoI and SacI sites for cloning into pKYLX7. The clones $\mathrm{pCP} \triangle 49$, $\mathrm{pCP} \triangle 77$, and $\mathrm{pCP} \triangle 146$ utilized start codons present in-frame within the TNVD ${ }^{\mathrm{H}} \mathrm{CP}$ coding sequence, and represent deletion of the first 49,77 and 146 codons of the $C P$ sequence, respectively. The clone pCP $\triangle 77 \mathrm{KO}$, the start codon has been changed to TTG.

The observation that TNVD triggers HR in most plant species is intriguing, because it suggests that these plants may contain receptors to recognize and defend against TNV infection. In the present study, 20 Nicotiana species representing the diversity of the Nicotiana genus were tested for their response to mechanical inoculation of $\mathrm{TNVD}^{\mathrm{H}}$. We found that 19 species responded to $\mathrm{TNVD}^{\mathrm{H}}$ infection with HR; in fact, $\mathrm{TNVD}^{\mathrm{H}}$ was able to move systemically in only one of the species, $N$. benthamiana. To determine whether the TNVD ${ }^{\mathrm{H}} \mathrm{CP}$ was capable of triggering HR in Nicotiana species, we expressed the TNVD ${ }^{\mathrm{H}}$ $\mathrm{CP}$ through agroinfiltration and found that HR is elicited in the same species of section Alatae that responded via HR to the TBSV CP [24]. Interestingly, a phylogenetic analysis of the tombusvirid CPs indicated that the $\mathrm{CP}$ of $\mathrm{TNVD}^{\mathrm{H}}$ is only distantly related to the CP of TBSV [10]. Consequently, we expanded our investigation of the tombusvirid CPs to representatives of selected genera within the family, evaluating each CP for silencing suppression as well as HR elicitation in Nicotiana. This analysis reinforces the phylogeny of the tombusvirid CPs of the Tombusviridae and illustrates how structural changes that occurred in the $\mathrm{CP}$ effector of two of the three progenitors of the current genera generally led to either silencing suppressor activity or HR elicitation in select Nicotiana species.

\section{Materials and Methods}

\subsection{Inoculation of Nicotiana Species with TNV Virions}

Seeds of different Nicotiana species were obtained from the U.S. Tobacco Germplasm Collection at North Carolina State University [31], as described in Angel and Schoelz [24]. To break dormancy, seeds were treated for $30 \mathrm{~min}$ with commercial bleach at $50 \%$ strength $(2.6 \%$ vol $/ \mathrm{vol} \mathrm{NaOCl})$. TNV- $\mathrm{D}^{\mathrm{H}}$ virions 
were initially inoculated to N. benthamiana and infected tissue was frozen for further inoculations. For inoculation of test plants, plant tissues infected with TNV- $\mathrm{D}^{\mathrm{H}}$ were ground with a mortar and pestle at a dilution of approximately 1:20 (wt/vol) with inoculation buffer (0.05 M phosphate buffer $\mathrm{pH} 7.0)$ and gently rubbed onto Nicotiana leaves dusted with 600-mesh carborundum.

\subsection{Coat Protein Constructs}

The TNV strain $\mathrm{D}^{\mathrm{H}}$ clone and virions were a gift from Dr. Lorant Kiraly (Hungarian Academy of Sciences); the infectious clone was developed by Molnár and coworkers ([26]; NCBI accession number U62546). The full-length clones of CyRSV ([32]; NCBI accession number X15511) and CNV ([33]; NCBI accession number M25270) were gifts from Dr. Herman Scholthof (Texas A\&M University). The full-length MCMV clone is from Dr. Kay Scheets (Oklahoma State University); its nucleotide sequence is described in Nutter et al. ([34]; NCBI accession number X14736). The full-length PMV clone was a gift from Dr. Karen Scholthof (Texas A\&M University); its nucleotide sequence is described in Turina et al. ([35]; NCBI accession number U55002). The MNSV CP clone was a gift from Dr. D'Ann Rochon; its nucleotide sequence is described in Riviere and Rochon ([36]; NCBI accession number M29671.1).

The CPs of TNV D ${ }^{\mathrm{H}}$, pCP $\Delta 49$, pCP $\Delta 77, \mathrm{pCP} \Delta 146, \mathrm{pCP} \Delta 77 \mathrm{KO}, \mathrm{CyRSV}, \mathrm{CNV}, \mathrm{MCMV}, \mathrm{MNSV}$, $\mathrm{MNeSV}$, and PMV clones were all amplified by PCR, and initially cloned into pGEM-T-Easy (Promega Corp., Madison, WI). Primers used for PCR amplification were synthesized by Integrated DNA Technologies (Coralville, IA, U.S.A.) and are listed in Supplemental Table S1. PCR conditions consisted of an initial denaturation at $94{ }^{\circ} \mathrm{C}$ for $5 \mathrm{~min}$, followed by 35 cycles at $95^{\circ} \mathrm{C}$ for $1 \mathrm{~min}, 55^{\circ} \mathrm{C}$ for $30 \mathrm{~s}$, $72{ }^{\circ} \mathrm{C}$ for $1 \mathrm{~min}$ and a final extension at $72{ }^{\circ} \mathrm{C}$ for $5 \mathrm{~min}$. The PCR product was purified by agarose gel elution using the QIAquick gel extraction kit (Qiagen Inc., Valencia, CA, U.S.A.) for cloning into pGEM-T-Easy. Escherichia coli colonies containing inserts were selected on Luria Bertani (LB) media containing $40 \mu \mathrm{L}$ XGal $(20 \mathrm{mg} / \mathrm{mL}), 10 \mu \mathrm{L}$ IPTG $(20 \%)$ and kanamycin $(50 \mu \mathrm{g} / \mathrm{mL})$. Candidate clones were sequenced in both orientations by the DNA Core Facility at the University of Missouri (Columbia, MO, U.S.A.). Once the fidelity of the sequence was confirmed, the insert was transferred into the Agrobacterium binary plasmid pKYLX7 digested with either XhoI or HindIII on the $5^{\prime}$ end and SacI on the $3^{\prime}$ end [24]. Restriction enzyme sites used for each CP clone are listed in the primer sequences in Supplemental Table S1. pKYLX7 plasmids carrying the CP insert were transformed into A. tumefaciens strain AGL1 [37] by electroporation with a PG200 Progenetor II (Hoefer Scientific Instruments, San Francisco, CA, U.S.A.). Transformants were selected on LB medium supplemented with kanamycin $(50 \mu \mathrm{g} / \mathrm{ML})$ and tetracycline $(12.5 \mu \mathrm{g} / \mathrm{mL})$.

The CP expression plasmids for RCNMV, TCV, PFBV, and PLPV were provided to us in Agrobacterium binary vectors. The RCNMV CP plasmid was a gift from Dr. Tim Sit (North Carolina State University). The RCNMV CP coding sequence (NCBI accession number J04357) was determined by Xiong et al. [38] and cloned into the Agrobacterium binary vector pPZP212 [39]. The TCV CP plasmid was a gift from Dr. Feng Qu (The Ohio State University). The cloning of the TCV CP sequence ([40]: NCBI accession number M22445) into the Agrobacterium binary vector PZP is described in Qu et al. [16]. The insertion of the TBSV CP construct into the Agrobacterium binary vector pKYLX7 was described previously [21]. The TBSV CP coding sequence was determined in Hearne et al. ([41]; NCBI Accession number M21958). The PFBV and PLPV CP constructs were cloned into the Agrobacterium binary vector pMOG800 under the control of the 35S promoter [21,23].

\subsection{Phylogenetic Analysis of the Tombusvirid CPS}

The alignment was made using MUSCLE while trees were generated with the Maximum Likelihood (ML) algorithm in MEGA7 [42] using 1000 boostrap replicates. All positions with less than 50\% site coverage were eliminated. That is, fewer than 50\% alignment gaps, missing data, and ambiguous bases were allowed at any position. 


\subsection{Agroinfiltration Assay for HR Elicitation and Silencing Suppression}

A. tumefaciens strains were grown in $3 \mathrm{Ml}$ LB broth supplemented with kanamycin $(50 \mu \mathrm{g} / \mathrm{mL})$ for $24 \mathrm{~h}$ at $28^{\circ} \mathrm{C}$ in an incubator shaker at $220 \mathrm{rpm}$. From each initial culture, $500 \mu \mathrm{L}$ was added to flasks with $40 \mathrm{~mL}$ LB broth containing kanamycin $(50 \mu \mathrm{g} / \mathrm{mL})$, and the cultures grown for an additional $24 \mathrm{~h}$. Bacteria were then sedimented by centrifugation at $14,000 \mathrm{~g}$ for $10 \mathrm{~min}$ and resuspended in $20 \mathrm{~mL}$ of infiltration solution ( $3.9 \mathrm{~g} / \mathrm{L} \mathrm{MES}, 20 \mathrm{~g} / \mathrm{L}$ Sucrose, $10 \mathrm{~g} / \mathrm{L}$ Glucose, $\mathrm{pH}$ 5.4) supplemented with $20 \mu \mathrm{L}$ $0.2 \mathrm{M}$ acetosyringone. Cells were incubated overnight at $28^{\circ} \mathrm{C}$ and $220 \mathrm{rpm}$ and cultures subsequently diluted to an $\mathrm{OD}_{600} 1.0$ immediately before infiltration into Nicotiana leaves as described in Angel and Schoelz [24]. After agroinfiltration, all plants were returned to the greenhouse where they were observed on a daily basis for HR.

For the silencing suppressor assay, the virus CPs, TBSV P19, and TCV CPs were co-agroinfiltrated into $N$. benthamiana leaves at equivalent optical densities with a GFP gene that had been cloned into the binary vector pKYLX7. The GFP clone and assay are described in Angel et al. [43]. Plants were examined for GFP expression using a Blak-Ray Long Wave Ultraviolet Lamp (Upland, CA), beginning at 2 days after infiltration (dai) and extending up to 10 dai.

\subsection{ELISA Assay for TNV CP expression}

Agroinfiltrated tissues were collected at $3 \mathrm{dpi}$ and ground with mortar and pestle at a ratio of 1:3 (tissue/grinding buffer). Grinding buffer consisted of $1 \times$ phosphate buffered saline, $2 \%$ polyvinylpyrrolidone MW 40,000 g/mol, $0.2 \%$ bovine serum albumin and $0.05 \%$ Tween 20 ). Double antibody sandwich ELISA (DAS-ELISA) was carried out using TNV-serotype D coating and alkaline phosphatase-conjugated secondary antibodies purchased from AC diagnostics (Fayetteville, AR, U.S.A.). Colorimetric reactions with the substrate p-nitrophenyl phosphate were quantified at $405 \mathrm{~nm}$ using a Multiskan MCC-340 microplate reader (Thermo Fischer Scientific, Cincinnati, OH, U.S.A.). All experiments were repeated three times.

\section{Results}

\subsection{Survey of Nicotiana Species for Resistance to $T N V D^{H}$ Virion Inoculations}

To examine the reaction of Nicotiana species to $\mathrm{TNVD}^{\mathrm{H}}, \mathrm{TNVD}^{\mathrm{H}}$ virions were rub-inoculated to leaves of 20 Nicotiana species that represent the diversity of the Nicotiana genus (Table 1). The same Nicotiana species had previously been used to characterize avr proteins present in the TBSV genome [24]. Eighteen of the twenty Nicotiana species responded to $\mathrm{TNVD}^{\mathrm{H}}$ inoculation with a hypersensitive response, defined here as the rapid development of necrosis in the inoculated leaf. Necrotic local lesions appeared between 2 to $5 \mathrm{dpi}$ and no systemic movement of the virus occurred in these plants (Table 1). Necrotic lesions varied in size, number per leaf, and timing. For example, N. quadrivalvis responded with large necrotic lesions that coalesced to cover nearly the entire leaf (Figure 2A), whereas $N$. forgetiana accession TW50, included in the same test, responded with fewer lesions (Figure 2B). Only one Nicotiana species, $N$. otophora, responded to $\mathrm{TNVD}^{\mathrm{H}}$ virion inoculation with chlorotic local lesions (Figure 2C), which developed much more slowly than the necrotic responses of the other Nicotiana species. Interestingly, no symptoms of $\mathrm{TNVD}^{\mathrm{H}}$ infection developed on upper, noninoculated leaves of $N$. otophora. It may mean that $N$. otophora is resistant to $\mathrm{TNVD}^{\mathrm{H}}$ or that the plants develop a symptomless systemic infection. N. benthamiana was the only Nicotiana species scored as susceptible to $\mathrm{TNVD}^{\mathrm{H}}$, as this plant species did develop systemic symptoms. N. benthamiana developed necrotic local lesions upon inoculation of $\mathrm{TNVD}^{\mathrm{H}}$ virions (Figure 2D) and as the virus moved into upper noninoculated leaves, those leaves developed a systemic necrosis symptom (Figure 2E), as described previously by Molnár et al. [26]. Consequently, the reactions of 18 of the Nicotiana species were classified as an HR type resistance, one was classified as resistant with no HR, and only one species was susceptible to $\mathrm{TNVD}^{\mathrm{H}}$ (Table 1). Supplemental Figures S1-4, illustrate the diversity of responses of all 20 Nicotiana species to $\mathrm{TNVD}^{\mathrm{H}}$ virion inoculations. 
Table 1. Response of 20 Nicotiana species to inoculation with TNV virions and agroinfiltration of the pTNV-CP.

\begin{tabular}{|c|c|c|c|}
\hline Nicotiana spp. & Section & TNV Virion Inoc.a & Agroinfiltration of pTNV-CP \\
\hline N. langsdorffii & Alatae & $\mathrm{HR}^{\mathrm{b}}$ & $\mathrm{N}^{\mathrm{c}}$ \\
\hline N. longiflora & Alatae & HR & $\mathrm{N}$ \\
\hline N. bonariensis & Alatae & HR & $\mathrm{N}$ \\
\hline N. alata & Alatae & HR & $\mathrm{N}$ \\
\hline N. forgetiana & Alatae & HR & $\mathrm{N}$ \\
\hline N. plumbaginifolia & Alatae & HR & no rxn ${ }^{d}$ \\
\hline N. quadrivalvis & Polydicliae & HR & no rxn \\
\hline N. clevelandii & Polydicliae & HR & no rxn \\
\hline N. edwardsonii ${ }^{d}$ & Undulatae/Polydicliae & HR & no rxn \\
\hline N. glutinosa & Undulatae & HR & no rxn \\
\hline N. arentsii & Undulatae & HR & no rxn \\
\hline N. undulata & Undulatae & HR & no rxn \\
\hline N. tabacum & Nicotiana & HR & no rxn \\
\hline N. sylvestris & Sylvestres & $\mathrm{HR}$ & no rxn \\
\hline N. otophora & Tomentosae & CLL $^{\mathrm{e}}$ & no rxn \\
\hline N. tomentosiformis & Tomentosae & HR & no rxn \\
\hline N. repanda & Repandae & HR & no rxn \\
\hline N. glauca & Noctiflorae & HR & no rxn \\
\hline N. rustica & Rusticae & HR & no rxn \\
\hline N. benthamiana & Suaveolentes & Susc $^{f}$ & no rxn \\
\hline
\end{tabular}

${ }^{a}$ Virions were present in sap from $N$. benthamiana leaves infected with TNV. ${ }^{b} \mathrm{HR}$, necrotic local lesions, no development of systemic symptoms. ${ }^{\mathrm{c}} \mathrm{N}$, rapid necrosis within the zone of infiltration. ${ }^{\mathrm{d}}$ no rxn, no visible reaction within the zone of infiltration. ${ }^{\mathrm{e}} \mathrm{CLL}$, chlorotic local lesions, no development of systemic symptoms. ${ }^{\mathrm{f}}$ Susceptible symptoms develop in upper, non-inoculated leaves.
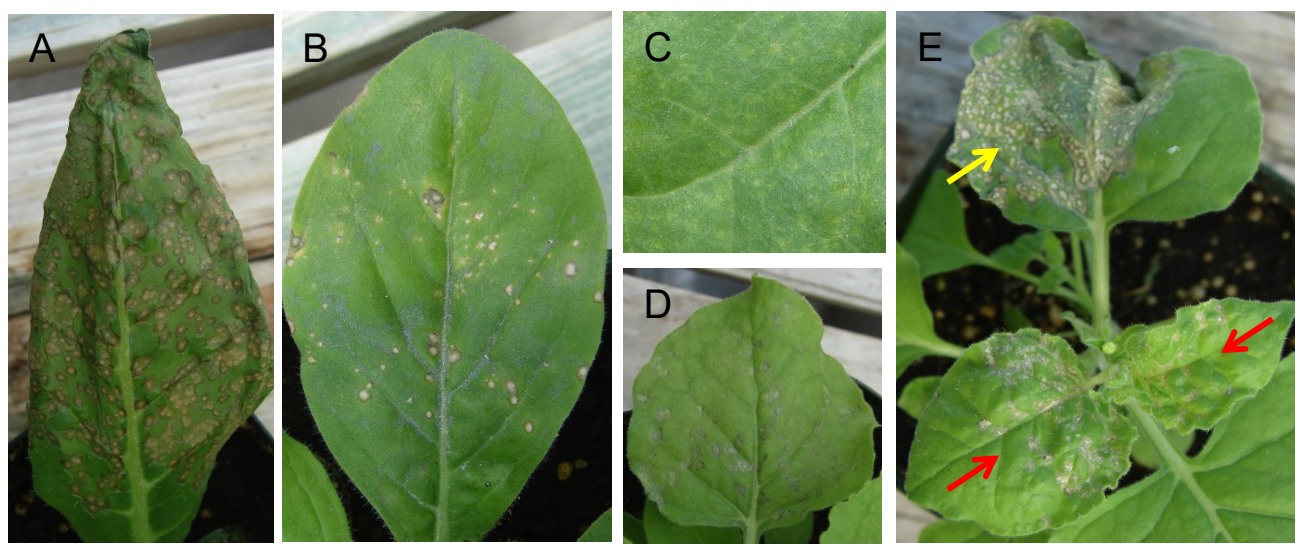

Figure 2. Response of Nicotiana species to $\mathrm{TNVD}^{\mathrm{H}}$ virion inoculation. (A) N. quadrivalvis at 3 dpi. (B) N. forgetiana TW50 at 5 dpi. (C) N. otophora at 3 dpi. (D ( N. benthamiana at 5 dpi. (E) N. benthamiana at $9 \mathrm{dpi}$. The red arrows indicate $N$. benthamiana leaves exhibiting systemic symptoms, whereas the yellow arrow indicates lesions in an inoculated leaf.

\subsection{The $T N V D^{H}$ Coat Protein Triggers HR in Nicotiana Species Section Alatae.}

A previous study had shown that a binary plasmid Agrobacterium tumefaciens expressing the coat protein $(\mathrm{CP})$ of Tomato bushy stunt virus elicited a rapid HR upon agroinfiltration into Nicotiana species belonging to section Alatae [24]. To investigate whether the TNVD ${ }^{\mathrm{H}} \mathrm{CP}$ was capable of triggering an $\mathrm{HR}$ in any Nicotiana species, we cloned the full-length $\mathrm{TNVD}^{\mathrm{H}} \mathrm{CP}$ coding sequence into the Agrobacterium tumefaciens binary vector pKYLX7 to create pTNV-CP (Figure 1). Upon agroinfiltration into leaves of each of the 20 Nicotiana species, pTNV-CP elicited HR in several species in section Alatae (Table 1), including the species N. langsdorffii, N. longiflora, N. bonariensis, N. alata, and N. forgetiana. Of the six species in section Alatae, only N. plumbaginifolia failed to respond to agroinfiltration of pTNV-CP with $\mathrm{HR}$, even with observations up to 10 dai. By contrast, HR was initiated in N. langsdorffii by pTNV-CP agroinfiltration as early as 2 dai and the tissue had completely collapsed by 3 dai (Figure 3). The 
TNVD $^{\mathrm{H}} \mathrm{CP}$ did not elicit HR in any of the other Nicotiana species included in our study (Table 1). The same five Nicotiana species that responded with HR to agroinfiltration of the $\mathrm{TNVD}^{\mathrm{H}}$ coat protein also responded with HR to agroinfiltration of a plasmid expressing the TBSV CP [24]. Interestingly, the CP of TBSV also did not trigger HR in the same two accessions of N. plumbaginifolia (24).

A previous analysis of the TBSV CP showed that the first 79 codons could be eliminated and the resultant $\mathrm{CP}$ deletion mutant was still capable of eliciting HR upon agroinfiltration into $N$. langsdorffii [21]. To determine the effect of N-terminal deletions on the capacity of pTNV-CP to trigger HR in an agroinfiltration assay, we deleted 49, 77, and 146 amino acids from the N-terminus of the TNVD ${ }^{\mathrm{H}}$ coding sequence. The sizes of the deletions were determined by the presence of start codons in-frame within the TNV $\mathrm{D}^{\mathrm{H}}$ coding sequence, the same strategy that was used for the choice of deletions in the TBSV CP. Both $\mathrm{pCP} \triangle 49$ and $\mathrm{pCP} \triangle 77$ triggered HR upon agroinfiltration into $N$. langsdorffii that was identical to $\mathrm{pTNV}-\mathrm{CP}$, whereas $\mathrm{pCP} \triangle 146$ did not elicit any response (Figure $3 \mathrm{~A}$ ). Furthermore, mutation of the start codon of $\mathrm{pCP} \triangle 77$ from ATG to TTG abolished HR elicitation, showing that $\mathrm{HR}$ was dependent on $\mathrm{TNVD}^{\mathrm{H}} \mathrm{CP}$ expression (Figure $3 \mathrm{~B}$ ). To verify that $\mathrm{TNVD}^{\mathrm{H}} \mathrm{CP}$ was expressed, total plant protein was isolated from leaves and $\mathrm{CP}$ was measured by ELISA. Figure $3 \mathrm{C}$ shows that $\mathrm{TNVD}^{\mathrm{H}} \mathrm{CP}$ epitopes were detected in leaf tissue agroinfiltrated with $\mathrm{pCP} 29$ and with $\mathrm{pCP} \triangle 77$. This experiment showed that the first 77 amino acids of the $\mathrm{TNVD}^{\mathrm{H}} \mathrm{CP}$ do not contribute to HR in N. langsdorffii, similar to an earlier finding that the first 79 amino acids of the TBSV CP do not contribute to HR in the same host [24].
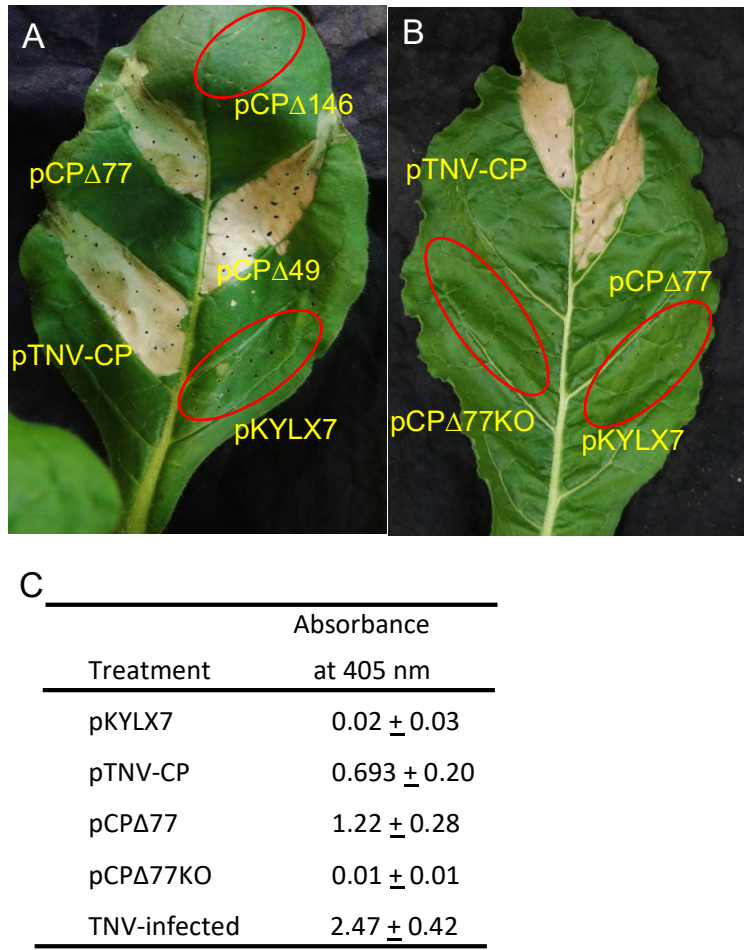

Figure 3. Agroinfiltration of pTNV-CP, N-terminal TNV CP deletion mutants, and empty vector pKYLX7 into N. langsdorffii at 3 dai. A. Analysis of TNV-CP and three deletion mutants. B. Analysis of TNV-CP, pCP $\triangle 77$ and $\mathrm{pCP} \triangle 77 \mathrm{KO}$. C. ELISA values assessed at $405 \mathrm{~nm}$ for expression of TNV CP constructs. Leaf panels infiltrated with constructs that do not react with $\mathrm{HR}$ are circled in red.

\subsection{Evaluation of the Coat Proteins of the Tombusviridae for Triggering HR in Members of Nicotiana} Section Alatae

A phylogenetic analysis of the CPs of the type members for each genus within the tombusvirus family revealed that TBSV and TNVD ${ }^{\mathrm{H}} \mathrm{CPs}$ are distantly related (Figure 4). Since both the TBSV and $\mathrm{TNVD}^{\mathrm{H}} \mathrm{CPs}$ triggered HR in the same five Nicotiana species within section Alatae, we hypothesized that 
CPs of other tombusvirid genera might elicit the same response. To test this hypothesis, we compared the capacity of CP genes from representatives tombusvirid genera to trigger HR in members of section Alatae and also compared their ability to function as silencing suppressors in N. benthamiana. To assess the capacity of the CPs from tombusvirids to elicit HR in section Alatae, we developed or obtained CP constructs representing 10 genera within the family. We also included the CPs of two additional viruses from the tombusvirus genus: Cucumber necrosis virus (CNV) and cymbidium ringspot virus (CyRSV).

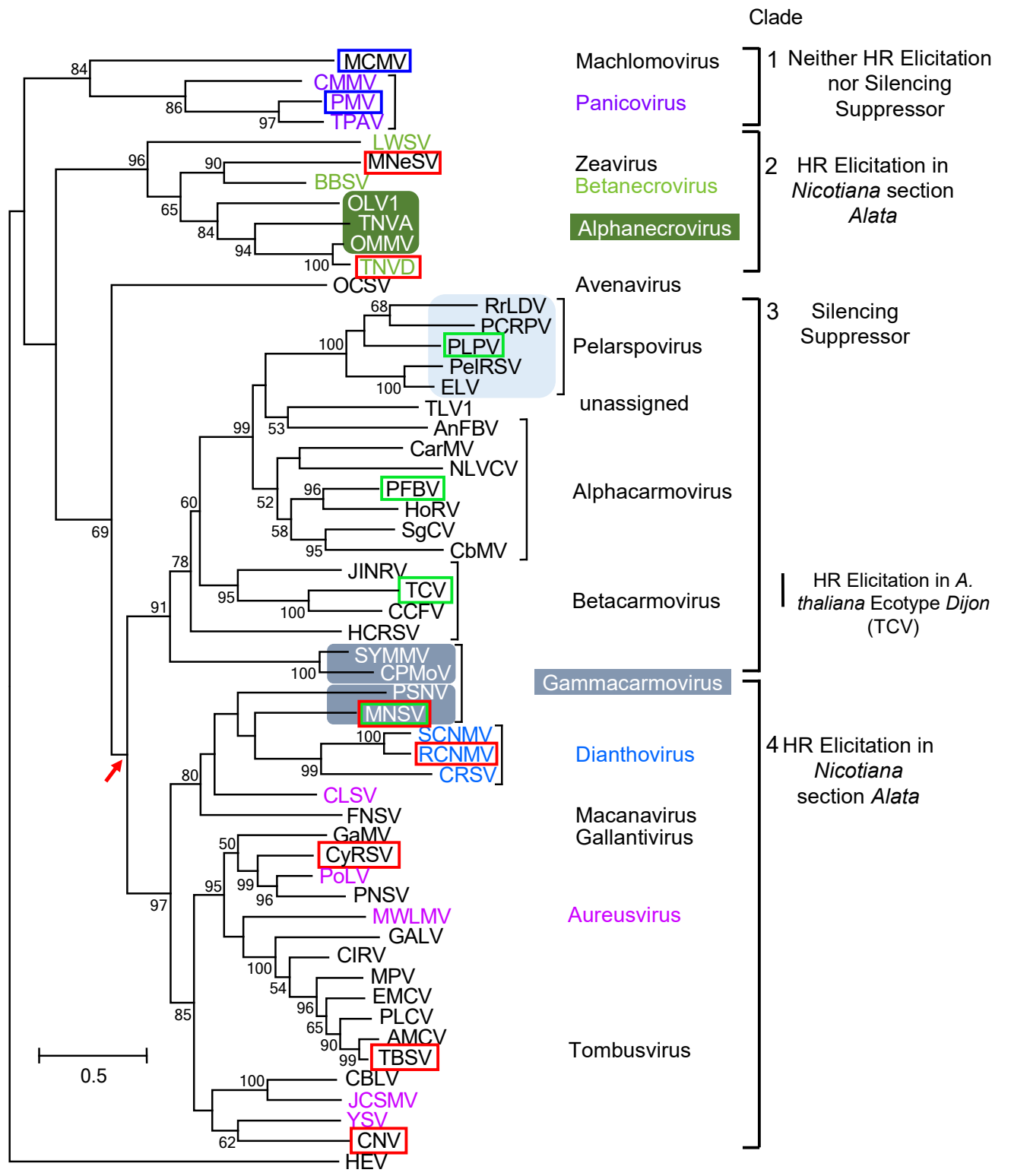

Figure 4. Phylogenetic (distance) analysis of $54 \mathrm{CPs}$ of CP-encoding tombusvirids. ML trees were generated as described in materials and methods. There were 356 positions in the final dataset. Hepatitis E virus (HEV) CP (AAA03191.1) was used as the outgroup. Brackets and/or colored text and/or colored boxes mark monophyletic RdRP lineages. Virus CPs enclosed in a red box were identified as avirulence determinants for the Nicotiana section Alatae. Virus CPs enclosed in a green box function as silencing suppressors in N. benthamiana. Virus CPs in blue boxes neither triggered HR in members of section Alatae nor acted as silencing suppressors. The arrow indicates a point of divergence between CPs that elicit HR in Nicotiana section Alata and CPs that function as silencing suppressors.

We initially tested representatives from the tombusvirus, dianthovirus, betacarmovirus, alphanecrovirus, panicovirus, and machlomovirus genera, and the agroinfiltration tests for N. langsdorffii 
are illustrated in Figure 5. Each of the CP constructs was agroinfiltrated into leaf panels of Nicotiana species section Alatae along with pTNV-CP, to ensure that environmental conditions and leaf age were conducive for HR development, and the empty vector pKYLX7, to test for development of any nonspecific necrosis associated with infiltration of Agrobacterium. Each CP construct was agroinfiltrated into at least three plants and three leaves per plant, for a minimum of nine infiltrations and plants were observed up to ten days after agroinfiltration. HR was consistently elicited in the leaf panel agroinfiltrated with $\mathrm{pTNV}-\mathrm{CP}$, as well as leaf panels agroinfiltrated with constructs that expressed the CPs of RCNMV, CNV, and CyRSV. In the case of the section Alatae species, all responded to agroinfiltration of the same set of CPs with HR except for accessions of TW106 and 108 of N. plumbaginifolia. A necrotic reaction appeared at 2 to 3 dai in N. langsdorffii, N. forgetiana (TW50 and TW51) and N. alata (TW7 and TW8) but in the case of N. longiflora it usually appeared between 4-6 dai. No HR was observed in leaf panels agroinfiltrated with constructs that expressed the CPs of MCMV, TCV and PMV. The results of all of the agroinfiltration tests are summarized in Table 2.
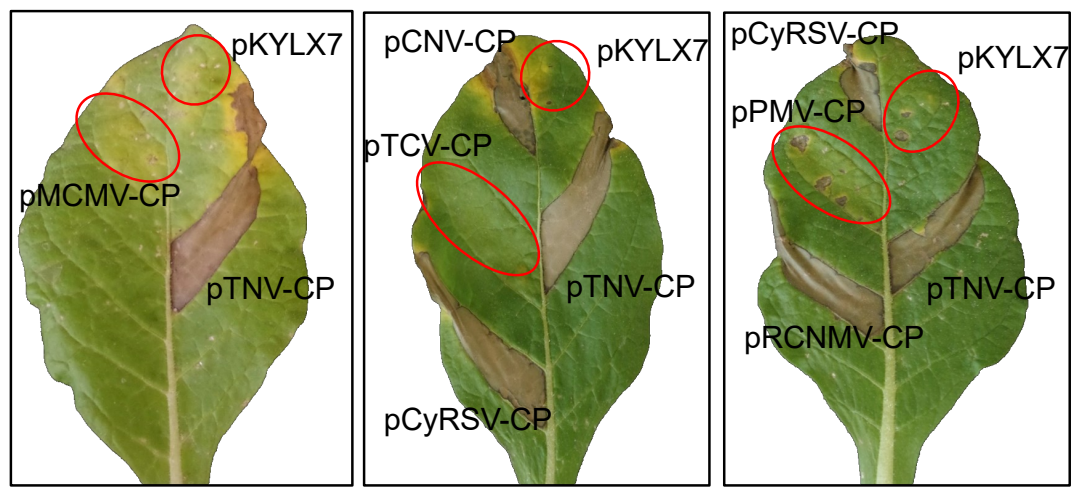

Figure 5. Evaluation of selected CPs of the Tombusviridae for elicitation of necrosis in N. langsdorffii. pTNV-CP and empty vector pKYLX7 were agroinfiltrated into every leaf as positive and negative controls, respectively. Red circles illustrate zones of infiltration for constructs that did not elicit necrosis. Photos were taken at 7 dai.

Table 2. Reaction of Nicotiana species in section Alatae to agroinfiltration of CPs of the Tombusviridae and assessment of silencing suppressor function of CPs in N. benthamiana.

\begin{tabular}{|c|c|c|c|c|c|c|}
\hline Virus CP & $\begin{array}{c}N . \\
\text { langsdorffii }\end{array}$ & N. longiflora & N. alata tw7 & $\begin{array}{l}N . \\
\text { forgetiana } \\
\text { tw50 }\end{array}$ & $\begin{array}{c}N . \\
\text { plumbaginifolia } \\
\text { tw106 }\end{array}$ & $\begin{array}{l}\text { Silencing } \\
\text { Suppressor } \\
\text { Activity }^{\text {a }}\end{array}$ \\
\hline \multicolumn{7}{|l|}{ tombusvirus } \\
\hline pTBSV & $\mathrm{N}^{\mathrm{b}}$ & $\mathrm{N}$ & $\mathrm{N}$ & $\mathrm{N}$ & no rxn ${ }^{c}$ & No \\
\hline pCyRSV & $\mathrm{N}$ & $\mathrm{N}$ & $\mathrm{N}$ & $\mathrm{N}$ & no rxn & No \\
\hline $\mathrm{pCNV}$ & $\mathrm{N}$ & $\mathrm{N}$ & $\mathrm{N}$ & $\mathrm{N}$ & no rxn & No \\
\hline gammacarmovirus & & & & & & \\
\hline $\begin{array}{l}\text { pMNSV } \\
\text { dianthovirus }\end{array}$ & $\mathrm{N}$ & $\mathrm{N}$ & $\mathrm{N}$ & $\mathrm{N}$ & no rxn & Yes \\
\hline $\begin{array}{c}\text { pRCNMV } \\
\text { betacarmovirus }\end{array}$ & $\mathrm{N}$ & $\mathrm{N}$ & $\mathrm{N}$ & $\mathrm{N}$ & no rxn & No \\
\hline $\begin{array}{c}\text { pTCV } \\
\text { pelarspovirus }\end{array}$ & no rxn & no rxn & no rxn & no rxn & no rxn & Yes \\
\hline $\begin{array}{c}\text { pPLPV } \\
\text { alphacarmovirus }\end{array}$ & no rxn & no rxn & no rxn & no rxn & no rxn & Yes \\
\hline $\begin{array}{c}\text { pPFBV } \\
\text { zeavirus }\end{array}$ & no rxn & no rxn & no rxn & no rxn & no rxn & Yes \\
\hline $\begin{array}{c}\text { pMNeSV } \\
\text { alphanecrovirus }\end{array}$ & $\mathrm{N}$ & $\mathrm{N}$ & $\mathrm{N}$ & $\mathrm{N}$ & no rxn & No \\
\hline $\begin{array}{c}\text { pTNV } \\
\text { panicovirus }\end{array}$ & $\mathrm{N}$ & $\mathrm{N}$ & $\mathrm{N}$ & $\mathrm{N}$ & no rxn & No \\
\hline $\begin{array}{c}\text { pPMV } \\
\text { machlomovirus }\end{array}$ & no rxn & no rxn & no rxn & no rxn & no rxn & No \\
\hline pMCMV & no rxn & no rxn & no rxn & no rxn & no rxn & No \\
\hline
\end{tabular}

${ }^{a}$ Silencing suppressor activity assessed by co-agroinfiltration of target CP with 35SGFP in N. benthamiana. ${ }^{b} \mathrm{~N}$, rapid necrosis within the zone of infiltration. ${ }^{\mathrm{C}}$ no rxn, no visible reaction within the zone of infiltration. 
We realized that there were significant gaps in the phylogenetic tree, and to address this issue we obtained CP clones for a gammacarmovirus, melon necrotic spot virus (MNSV), the aphacarmovirus pelargonium flower break virus (PFBV), a betacarmovirus, pelargonium line pattern virus (PLPV), and the zeavirus maize necrotic streak virus (MNeSV). In these tests, pTNV-CP was used as the positive control and pTCV-CP was used as the negative control. We found that pMNSV-CP and pMNeSV-CP constructs induced HR in N. langsdorffii, N. fogetiana and N. alata, but did not induce HR in N. plumbaginifolia. By contrast, pPLPV-CP and pPFBV-CP did not induce HR in any of the Nicotiana species in section Alatae (results illustrated for N. langsdorffii, Suppl. Figure 5, Table 2).

An inspection of the phylogenetic tree constructed for tombusvirid CPs shows that Clades 2 and 4 have retained the capacity to trigger HR in members of Nicotiana section Alatae (Figure 4). HR elicitation was confirmed for two CPs within Clade 2: The betanecrovirus TNV D and the zeavirus MNeSV. Furthermore, HR elicitation was also confirmed within Clade 4 for five CP sequences within the genera: three tombusviruses (TBSV, CNV, CyRSV), the dianthovirus RCNMV, and the gammacarmovirus MNSV.

\subsection{Evaluation of the CPs of Selected Tombusvirids for a Functional Silencing Suppressor in N. benthamiana}

CPs of several of the tombusvirids have been shown to function as a silencing suppressor: betacarmoviruses TCV and Hibiscus chlorotic ringspot virus (HCRSV) [16,17,22], alphacarmovirus PFBV [21], gammacarmovirus MNSV [20], and pelarspovirus PLPV [23]. In each case, GFP expression has been enhanced and extended when a binary plasmid designed to express GFP is co-agroinfiltrated into N. benthamiana leaves with plasmids containing one of these CPs. By contrast, the CP of MCMV does not act to enhance and extend the expression of GFP in the standard silencing suppressor assay that works for HCRSV, PFBV, MNSV, TCV and PLPV [44].

To investigate whether the TNV CP had the capacity for silencing suppression, we co-agroinfiltrated pTNV-CP with p35S-GFP into $N$. benthamiana leaves and evaluated GFP expression over a period of 8-10 days. GFP expression in leaf sections agroinfiltrated with p35S-GFP alone or co-agroinfiltrated with pTNV-CP peaked at 3-4 dai and by 8 dai, GFP expression was extinguished (Figure 6). By contrast, GFP expression remained strong in leaf sections co-agroinfiltrated with p35S-GFP and plasmids containing TCV CP or TBSV P19. This test showed that TNV D ${ }^{\mathrm{H}} \mathrm{CP}$ does not function as a silencing suppressor analogous to TCV CP or TBSV P19. To our knowledge, the CPs of several other tombusviruses have not been formally evaluated for silencing suppression. We found that none of the CPs of CNV, MCMV, PMV, CyRSV or MNeSV displayed silencing suppressor activity (Figure 6, Table 2). Of the tombusvirid CPs previously found to be silencing suppressors, we confirmed this activity for the CPs of PLPV, PFBV, and MNSV, whereas the CPs of TBSV and RCNMV were confirmed to have no silencing suppressor function (Figure S6, Table 2). In tracing the lineage of silencing suppressor function for the tombusvirid CPs, the trait appears to be confined to Clade 3, with the one exception of the gammacarmovirus CP of MNSV, which is located in Clade 4 (Figure 4). 

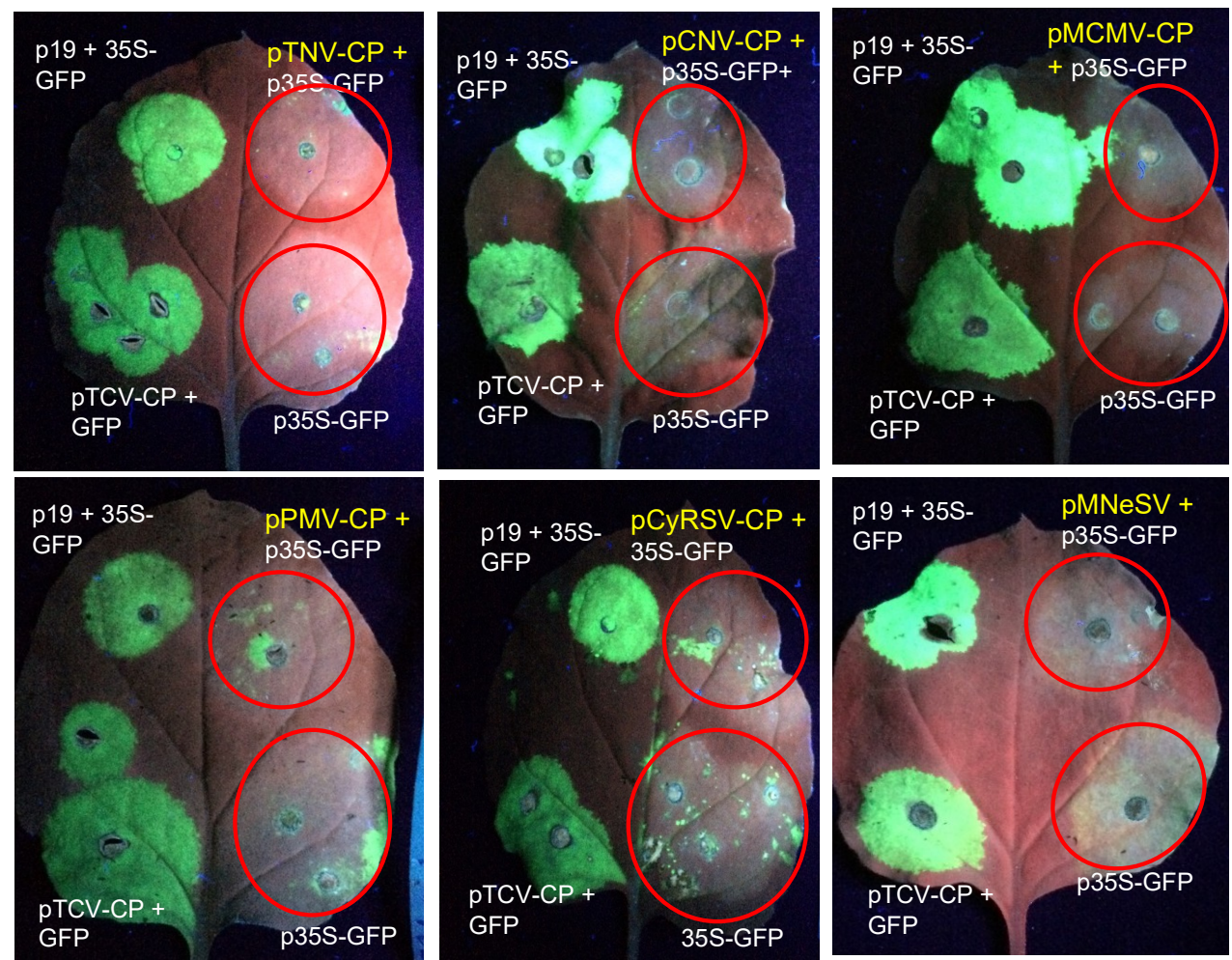

Figure 6. Agroinfiltration of p35S-GFP alone or co-agroinfiltration with virus CP clones or TBSV $\mathrm{p} 19$. The clones $\mathrm{pTCV}-\mathrm{CP}$ and TBSV p19 were included in each leaf as positive controls for silencing suppression, whereas p35S-GFP was included in each leaf to illustrate the induction of the host silencing response. The zone of infiltration is highlighted in tissues that did not exhibit silencing suppression. Photos were taken under UV illumination between 8-10 dai.

\section{Discussion}

Agroinfiltration is a powerful tool for the discovery and initial characterization of pathogen proteins capable of triggering HR in plant hosts. This tool has been validated for several virus avr proteins including the cauliflower mosaic virus $\mathrm{P} 6$ protein [45] and the helicase domain of the tobacco mosaic virus (TMV) replicase [46,47], the NSm gene of tomato spotted wilt virus (TSWV) [48] as well as the P19 and P22 proteins of TBSV [40]. For each of these virus avr genes, the avr trait was first identified through techniques involving either gene swaps between virus strains [49,50], the insertion of the avr gene into a virus vector [51,52], or direct mutagenesis of the avr gene within an infectious clone of the virus [53]. The capacity for HR was then confirmed through agroinfiltration of the viral gene, separate from the virus genome. Agroinfiltration has also been used as the initial technique for characterization of virus avr genes. For example, it has been used to show that the NSs protein of TSWV triggers HR in Capsicum annuum species resistant to the virus infection [54]. Furthermore, the $\mathrm{CP}$ gene of Potato virus $\mathrm{X}(\mathrm{PVX})$ was shown to induce HR upon its co-agroinfiltration with its $R$ gene counterpart into N. benthamiana [55]. Recently, Vleeshouwers and coworkers [56] utilized agroinfiltration to initially characterize the capacity of 54 effectors of Phytophthora infestans to trigger HR in wild Solanum species, illustrating how this technique could accelerate discovery and functional analysis of pathogen avr genes.

In a previous paper, Angel and Schoelz [24] showed that the TBSV CP triggered HR in several members of Nicotiana section Alatae, including N. alatae, N. langsdorffii, N. forgetiana, N. bonariensis, and $N$. longiflora. In the present paper we have now extended this analysis to show that the same Nicotiana species in section Alatae that recognized the TBSV CP also recognize the CPs of several other tombusvirids. This analysis has implications for the lineage of the avr motif (or motifs) associated with the tombusvirid CPs as well as the lineage for the silencing suppressor function associated with the CP. 


\subsection{Tracing the Lineage of HR Induction and Silencing Suppression Associated with the CPs of the Tombusviridae}

In this paper we considered the CPs of individual tombusvirid species to be structural variants of a single effector. Consequently, a phylogenetic tree of the CPs can be a valuable source of information on the traits associated with the $\mathrm{CP}$, just as phylogenetic trees of host plants can be informative about the inheritance of resistance. The two traits we evaluated in this paper were the capacity to trigger HR in Nicotiana species of section Alatae and silencing suppression. Silencing suppressor activity associated with the tombusvirid $\mathrm{CP}$ has been characterized in several papers $[16,17,20-23]$. Our goal in the present paper was to characterize the status of silencing suppressor activity in virus species for which there are no published records. Furthermore, we considered it valuable to test silencing suppressor activity and $\mathrm{HR}$ elicitation of $\mathrm{CP}$ constructs under a uniform set of conditions.

We found that elicitation of HR in Nicotiana could be traced to CPs in two clades: Clades 2 and 4 (Figure 4). In Clade 2, elicitation of HR was confirmed in one betanecrovirus and the monotypic zeavirus (Figure 4); it remains to be seen whether the CPs of the alphanecroviruses also have the capacity to trigger HR in Nicotiana. In Clade 4, HR elicitation in Nicotiana was confirmed by one or more tombusvirus, gammacarmovirus, and dianthovirus, but must still be investigated in aureusviruses, and the single gallantivirus, and macanavirus (Figure 4). Further work is necessary to determine whether an amino acid motif common to the CPs in Clades 2 and 4 is recognized by a single R protein in Nicotiana, or whether recognition is mediated by motifs unique to each of the clades.

An intriguing result is that viruses in Clade 1, which are the only tombusvirids that produce small CPs lacking a protruding domain, had neither HR elicitation nor silencing suppressor function, and hosts for MCMV and panicoviruses are restricted to the family Poaceae. MNeSV is likewise restricted to hosts in the family Poaceae, but nt sequence analysis indicated that the homology to tombusviruses surrounding the necrovirus-like CP ORF had borders that precisely retain two tombusviral regulatory sequences [12]. Thus, it is apparent that MNeSV has not lost the betanecrovirus CP characteristics that induced necrosis. The host range of the macanavirus furcrea necrotic streak virus is restricted to members of the monocot family Asparagaceae, [57] which may limit the ability of its CP, which contains a protruding domain, to cause any effect in dicot species.

In tracing the lineage of silencing suppression within the $\mathrm{CP}$, we found that the silencing suppressor function was largely confined to Clade 3 (Figure 4). A comparison of the CPs in Clades 3 and 4 show that the silencing suppression trait in Clade 3 can be genetically separated from the HR determinant in Clade 4. In fact, the phylogenetic tree for the $\mathrm{CP}$ suggests that the separation of these traits occurred in a progenitor that led to the occurrence of Clades 3 and 4 (Figure 4, red arrow). It is significant to note that silencing suppressor function has been attributed to proteins other than the $\mathrm{CP}$ in many of the virus species in Clade 4, such as the strong silencer P19 in the tombusvirus genus [2] and both the RCNMV replication complex and MP [58,59]. Consequently, the CPs of the viruses in Clade 4 might not have a need to function as silencing suppressors.

The one intriguing exception to the separation of silencing suppressor and HR determinant is found in the CP of MNSV, as it carries both traits. Interestingly, phylogenetic analyses of the RdRP and movement proteins of tombusvirids showed that these proteins are more closely aligned with the other members of the gammacarmovirus genus in Clade 3 than with any member of Clade 4 [10], suggesting a recombination event occurred between MNSV and some member of Clade 4 to orient the MNSV CP in Clade 4. Indeed, interfamilial recombination has already been documented between the $3^{\prime}$ untranslated region of MNSV and the polerovirus cucurbit aphid-borne yellows virus, a luteovirid [60], so it is possible that other recombination events might have placed the MNSV CP ORF in Clade 4 and the balance of the virus in Clade 3.

The MNSV CP demonstrates that although separate, the motifs for HR elicitation in Nicotiana and silencing suppression can coexist in the same protein sequence. This conclusion is similar to what has been found with the $\mathrm{CP}$ of TCV, which also carries motifs for silencing suppression and HR elicitation in A. thaliana ecotype Dijon [13-17]. Choi and coworkers [18] also concluded that HR elicitation and 
silencing suppression were separate traits. Interestingly, the motif in the TCV CP that elicits HR in Dijon is likely located in a different part of the $\mathrm{CP}$ than the motif in the CPs that triggers HR in Nicotiana. In the case of the TCV CP, the amino acids responsible for breaking resistance in Dijon have been localized to the N-terminus of the TCV CP $[14,61]$. By contrast, deletion analyses of the CPs of TBSV and $\mathrm{TNVD}^{\mathrm{H}}$ have shown that the capacity to trigger HR in Nicotiana section Alatae is retained in CPs in which the first 77 amino acids can be deleted.

The interplay between resistance and susceptibility is frequently portrayed as an arms race between the pathogen and host in which any advantage gained by one side is countered by modifications on the other to nullify that advantage $[3,5,62]$. Similarly, it has also been suggested that viral silencing suppressors may be preferentially targeted by the host, perhaps to protect the integrity of the host silencing apparatus $[3,52,54,62,63]$. In this scenario, host $\mathrm{R}$ proteins have arisen to counter the silencing suppression function of the virus protein. However, the phylogenetic analysis in Figure 4 is striking because it indicates that there may not be any obvious relationship between the development of the $\mathrm{CP}$ as a silencing suppressor and its selection as a target for HR elicitation by the host. With the exception of MNSV, the CPs in Clade 4 that are the target for HR elicitation by members of Nicotiana Section Alatae have all lost the capacity of silencing suppression, whereas an $\mathrm{R}$ protein has not yet been identified that can uniformly recognize the $\mathrm{CPs}$ that retain silencing suppressor function. An alternative hypothesis would be that the silencing suppression and avr traits may be associated with structural requirements of the virion, traits that became set in the $\mathrm{CP}$ progenitors that resulted in the separation of Clades 3 and 4 .

The three-dimensional structure of the CPs of several tombusvirids have been determined (reviewed in [64]), and coupled with the wealth of amino acid sequence information on tombusirid $\mathrm{CPs}$, it would be valuable now to further examine the structural basis for silencing suppression and for elicitation of HR. In fact, amino acid sequences associated with the silencing suppressor function of the TCV CP were characterized in Cao et al. [19]; in particular, mutation of two basic amino acid residues (R130 and R137) appeared to have a significant effect on silencing activity. With the increased number and diversity of $\mathrm{CP}$ sequences now available, it would be interesting to continue with this analysis. It is possible that both silencing suppression and HR elicitation may be associated as much with the secondary and tertiary structure of the $\mathrm{CP}$ rather than with the primary amino acid sequences. A similar analysis of the $\mathrm{CP}$ effector of TMV was completed several years ago, showing that the three-dimensional structure of the coat protein is critical for recognition by the $N^{\prime}$ gene. The recognition site consists of a central hydrophobic core surrounded by polar and charged amino acid resides [65]. In addition, the formation of coat protein dimers, trimers, and tetramers may also influence recognition [66]. It would be interesting to know if the sequence in the CPs of the members of Clades 2 and 4 recognized by at least one putative R protein in Nicotiana also is as complex as the TMV CP elicitor.

\subsection{Tracing the Lineage of Resistance Genes to the Tombusviridae in the Genus Nicotiana}

Many Nicotiana species respond to TBSV and TNV virion inoculation with HR, and putative R genes within these species target at least three different TBSV proteins (24). The P19 protein triggers HR in N. tabacum, N. sylvestris, and N. bonariensis [24,51]. Similarly, the P22 gene triggers HR in N. glutinosa and $N$. forgetiana TW50 [24,51]. Since most tombusvirids do not carry genes comparable to P19 and P22, these R proteins would appear to be targeting primarily members of the genus tombusviruses and aureusviruses. However, a third type of $\mathrm{R}$ gene has evolved to target a broader range of the tombusvirids, as our evidence indicates that several species of Nicotiana section Alatae can recognize the CPs of tombusviruses [24], dianthovirus, gammacarmovirus, betanecrovirus and zeavirus.

These results illustrate the potential for characterizing resistance genes in Nicotiana species towards different viruses and strains of the same virus. For instance, Doroszewska and Depta [67] inoculated virions of six isolates of Potato virus Y (PVY) from three groups, $\mathrm{PVY}^{\mathrm{NW}}$, $\mathrm{PVY}^{\mathrm{NZ}}$ and PVY ${ }^{\mathrm{NTN}}$, on leaves of 96 accessions of 68 Nicotiana species, including autotetraploid forms and botanical varieties. Five accessions belonging to N. africana, N. glauca, N. raimondii, N. knightiana and N. benavidesii were fully resistant to the six PVY isolates, but several other accessions and species were resistant to one or 
more PVY isolates, varying in their response. Similarly, Laskowska et al [68] tested 94 accessions of Nicotiana species accessions against TSWV and found that members of the Alatae section were mostly resistant, including five accessions in N. alata, N. forgetiana, three accessions of Nicotiana x sanderae, and also two N. tabacum cultivars showed HR local or systemic related resistance to TSWV.

Interestingly, a recent study has shown that several members of Nicotiana section Alatae also carry a functional orthologue of the $N^{\prime}$ gene, which recognizes the CP of TMV [69]. Members of section Alatae that carry a functional orthologue include N. alatae (PI42334), N. forgetiana, and N. langsdorffii. It is intriguing that these Nicotiana species are able to respond with HR to inoculation of viruses from such genera as tobamovirus, tombusvirus, and betanecrovirus, and that these species respond to an even larger selection of CPs with HR upon agroinfiltration. It would be interesting to know if there is a common $\mathrm{R}$ protein in these Nicotiana species responsible for recognition these viruses. It may be that an $N$ or $N^{\prime}$ homologue might condition resistance in Nicotiana to tombusvirids. Yuan and coworkers [69] reported that Nicotiana species carried from one to up to 22 distinct $N$ homologues, whereas Balaji et al. [70] found evidence for approximately $14 \mathrm{~N}$ homologues in $\mathrm{N}$. clevelandii and N. glutinosa, in addition to the N gene. Significantly, silencing of the $N$ gene present in N. edwardsonii suppressed HR induced by inoculation of TBSV and CymRSV, as well as TMV, suggesting that a Tombusvirus R gene shares some homology with the $N$ gene.

Supplementary Materials: The following are available online at http://www.mdpi.com/1999-4915/11/7/588/s1, Figure S1: Response of Nicotiana species to $\mathrm{TNVD}^{\mathrm{H}}$ virion inoculation. Figure S2: Response of Nicotiana species to $\mathrm{TNVD}^{\mathrm{H}}$ virion inoculation. Figure S3: Response of Nicotiana species to $\mathrm{TNVD}^{\mathrm{H}}$ virion inoculation. Figure S4: Response of Nicotiana species to TNVD ${ }^{\mathrm{H}}$ virion inoculation. Figure S5: Evaluation of selected tombusvirid CPs for elicitation of necrosis in N. langsdorffii. Figure S6: Agroinfiltration of p35S-GFP alone or co-agroinfiltration with virus CP clones or TBSV p19. Table S1: PCR primers used for cloning tombusvirid CP sequences. Table S2: List of virus isolate acronyms, along with the full name of the virus species used in Figure 4.

Author Contributions: Experiments conceived and designed by J.E.S., M.A., L.K., and C.A.; experiments were performed by M.A., J.E.S., C.A., A.R. and M.F.; the data was analyzed by M.A., J.E.S., C.A., A.R., L.K., K.S. and M.F.; reagents/materials were provided by J.E.S., L.K., and K.S. Portions of the original draft was written by M.A., J.E.S., C.A., A.R. and M.F.; the review and editing was conducted by M.A., J.E.S., K.S., and C.A. J.E.S. was responsible for supervision, project administration and funding acquisition.

Acknowledgments: The authors wish to thank Tim Sit for the gift of the RCNMV CP clone, Feng Qu for the gift of the TCV CP clone, Carmen Hernandez Fort for the gifts of the CP clones for PFBV and PLPV, Karen-Beth Scholthof for the gift of the PMV CP clone, D'Ann Rochon for the gift of the MNSV clone, and Sandra Valdes for technical assistance. M.A.A. was supported through a fellowship from HCED-Iraq and the D.F. Millikan Endowment at the University of Missouri, L.K. is funded by the Hungarian National Research, Development and Innovation Office (NKFIH grant K-128868). This research was also partially funded through the Missouri Agricultural Experiment Station.

Conflicts of Interest: The authors declare no conflict of interest. The funders had no role in the design of the study; in the collection, analyses, or interpretation of data; in the writing of the manuscript, or in the decision to publish the results.

\section{References}

1. Qu, F.; Morris, T.J. Suppressors of RNA silencing encoded by plant viruses and their role in viral infections. FEBS Lett. 2005, 579, 5958-5964. [CrossRef] [PubMed]

2. Scholthof, H.B. The tombusvirus-encoded P19: From irrelevance to elegance. Nat. Rev. Microbiol. 2006, 4, 405-411. [CrossRef] [PubMed]

3. deRonde, D.; Butterbach, P.; Kormelink, R. Dominant resistance against plant viruses. Front. Plant Sci. 2014, 5, 307. [CrossRef]

4. Mandadi, K.K.; Scholthof, K.-B.G. Plant immune responses against viruses: How does a virus cause disease? Plant Cell 2013, 25, 1489-1505. [CrossRef] [PubMed]

5. Zvereva, A.S.; Pooggin, M.M. Silencing and innate immunity in plant defense against viral and non-viral pathogens. Viruses 2012, 4, 2578-2597. [CrossRef] [PubMed]

6. Leisner, S.M.; Schoelz, J.E. Joining the crowd: Integrating plant virus proteins into the larger world of pathogen effectors. Annu. Rev. Phytopathol. 2018, 56, 89-110. [CrossRef] [PubMed] 
7. Schoelz, J.E. Viral determinants of resistance and susceptibility. In Natural Resistance Mechanisms of Plant to Viruses; Loebenstein, G., Carr, J., Eds.; Springer: Dordrecht, The Netherlands, 2006; pp. 13-43.

8. Rochon, D.; Rubino, L.; Russo, M.; Martelli, G.P.; Lommel, S. Tombusviridae. In Virus Taxonomy-Ninth Report of the International Committee on Taxonomy of Viruses; King, A.M.Q., Adams, M.J., Carstens, E.B., Lefkowitz, E.J., Eds.; Academic Press: London, UK, 2012; pp. 1111-1138.

9. Scheets, K.; White, K.A.; Rubino, L.; Martelli, G.P.; Rochon, D.A. ICTV taxonomic proposal 2015.007a-rP.A.v1.split_Carmovirus. Divide the Genus Carmovirus (family Tombusviridae) into Three New Genera: Alphacarmovirus, Betacarmovirus, and Gammacarmovirus. 2015. Available online: https: //talk.ictvonline.org/ICTV/proposals/2015.007a-rP.A.v1.split_Carmovirus.pdf (accessed on 20 May 2019).

10. Scheets, K.; Jordan, R.; White, A.; Hernandez, C. ICTV taxonomic proposal 2014.006b-fP.A..v3.Pelarspovirus. In the family Tombusviridae assign 5 previously unassigned species to a new genus, Pelarspovirus. 2014. Available online: https://talk.ictvonline.org/files/ictv_official_taxonomy_updates_since_the_8th_report/m/ plant-official/5847 (accessed on 20 May 2019).

11. Adams, M.J.; King, A.M.; Carstens, E.B. Ratification vote on taxonomic proposals to the International Committee on Taxonomy of Viruses (2013). Arch. Virol. 2013, 158, 2023-2030. [CrossRef]

12. Scheets, K.; Redinbaugh, M.G. Infectious cDNA transcripts of maize necrotic streak virus: Infectivity and translational characteristics. Virology 2006, 350, 171-183. [CrossRef]

13. Oh, J.-W.; Kong, Q.; Song, C.; Carpenter, C.D.; Simon, A.E. Open reading frames of Turnip crinkle virus involved in satellite symptom expression and incompatibility with Arabidopsis thaliana ecotype Dijon. Mol. Plant-Microbe. Interact. 1995, 8, 979-987. [CrossRef]

14. Zhao, Y.; DelGrosso, L.; Yigit, E.; Dempsey, D.A.; Klessig, D.F.; Wobbe, K.K. The amino terminus of the coat protein of Turnip crinkle virus is the AVR factor recognized by resistant Arabidopsis. Mol. Plant-Microbe Interact. 2000, 13, 1015-1018. [CrossRef]

15. Qu, F.; Morris, T.J. Efficient infection of Nicotiana benthamiana by Tomato bushy stunt virus is facilitated by the coat protein and maintained by 19 through suppression of gene silencing. Mol. Plant-Microbe Interact. 2002, 15, 193-202. [CrossRef] [PubMed]

16. Qu, F.; Ren, T.; Morris, T.J. The coat protein gene of turnip crinkle virus suppresses posttranscriptional gene silencing at an early initiation step. J. Virol. 2003, 77, 511-522. [CrossRef] [PubMed]

17. Thomas, C.L.; Leh, V.; Lederer, C.; Maule, A.J. Turnip crinkle virus coat protein mediates suppression of RNA silencing in Nicotiana benthamiana. Virology 2003, 306, 33-41. [CrossRef]

18. Choi, C.W.; Qu, F.; Ren, T.; Ye, X.; Morris, T.J. RNA silencing-suppressor function of Turnip crinkle virus coat protein cannot be attributed to its interaction with the Arabidopsis protein TIP. J. Gen. Virol. 2004, 85, 3415-3420. [CrossRef] [PubMed]

19. Cao, M.; Ye, X.; Willie, K.; Lin, J.; Zhang, X.; Redinbaugh, M.G.; Simon, A.E.; Morris, T.J.; Qu, F. The capsid protein of turnip crinkle virus overcomes two separate defense barriers to facilitate systemic movement of the virus in Arabidopsis. J. Virol. 2010, 84, 7793-7802. [CrossRef] [PubMed]

20. Genovés, A.; Navarro, J.A.; and Pallás, V. Functional analysis of the five melon necrotic spot virus genome-encoded proteins. J. Gen. Virol. 2006, 87, 2371-2380. [CrossRef]

21. Martinez-Turiño, S.; Hernandez, C. Inhibition of RNA silencing by the coat protein of pelargonium flower break virus: Distinctions from closely related suppressors. J. Gen. Virol. 2009, 90, 519-525. [CrossRef]

22. Meng, C.; Chen, J.; Peng, J.; Wong, S.M. Host-induced avirulence of Hibiscus chlorotic ringspot virus mutant correlates with reduced gene-silencing suppression activity. J. Gen. Virol. 2006, 87, 451-459. [CrossRef]

23. Pérez-Cañamás, M.; Hernández, C. Key importance of small RNA binding for the activity of a glycine/tryptophan (GW) motif-containing viral suppressor of RNA silencing. J. Biol. Chem. 2015, 290, 3106-3120. [CrossRef]

24. Angel, C.A.; Schoelz, J.E. A survey of resistance to tomato bushy stunt virus in the genus Nicotiana reveals that the hypersensitive response is triggered by one of three different viral proteins. Mol. Plant-Microbe Interact. 2013, 26, 240-248. [CrossRef]

25. Coutts, R.H.A.; Rigden, J.E.; Slabas, A.R.; Lomonosssoff, G.P.; Wise, P.J. The complete nucleotide sequence of tobacco necrosis virus strain D. J. Gen. Virol. 1991, 72, 1521-1529. [CrossRef] [PubMed]

26. Molnár, A.; Havelda, Z.; Dalmay, T.; Szutorisz, H.; and Burgyan, J. Complete nucleotide sequence of tobacco necrosis virus strain DH and genes requried for RNA replication and virus movement. J. Gen. Viol. 1997, 78, 1235-1239. [CrossRef] [PubMed] 
27. Chkuaseli, T.; Newburn, L.R.; Bakhshinyan, D.; White, K.A. Protein expression strategies in tobacco necrosis virus-D. Virology 2015, 486, 54-62. [CrossRef] [PubMed]

28. Fang, L.; Coutts, R.H. Investigations on the tobacco necrosis virus D p60 replicase protein. PLoS ONE 2013, 8, e80912. [CrossRef] [PubMed]

29. Price, W.C. Host ranges of six plant viruses. Am. J. Bot. 1940, 27, 530-541. [CrossRef]

30. Bascó, R.; Künstler, A.; Király, L. Tobacco necrosis virus replication and spread in Arabidopsis thaliana ecotype Columbia: A potential system for studying plant defense reactions to symptomless virus infections. Acta Physiol. Plant. 2016, 38, 139. [CrossRef]

31. Lewis, R.S.; Nicholson, J.S. Aspects of the evolution of Nicotiana tabacum L. and the status of the Nicotiana Germplasm Collection. Genet. Resour. Crop Evol. 2007, 54, 727-740. [CrossRef]

32. Grieco, F.; Burgyan, J.; Russo, M. The nucleotide sequence of cymbidium ringspot virus RNA. Nucleic Acids Res. 1989, 17, 6383. [CrossRef]

33. Rochon, D.; Tremaine, J. Complete nucleotide sequence of the cucumber necrosis virus genome. Virology 1989, 169, 251-259. [CrossRef]

34. Nutter, R.C.; Scheets, K.; Panganiban, L.C.; Lommel, S.A. The complete nucleotide sequence of the maize chlorotic mottle virus genome. Nucl. Acids Res. 1989, 17, 3163-3177. [CrossRef]

35. Turina, M.; Maruoka, M.; Monis, J.; Jackson, A.O.; Scholthof, K.B. Nucleotide sequence and infectivity of a full-length cDNA clone of panicum mosaic virus. Virology 1998, 241, 141-155. [CrossRef] [PubMed]

36. Riviere, C.J.; Rochon, D.M. Nucleotide sequence and genomic organization of melon necrotic spot virus. J. Gen. Virol. 1990, 71, 1887-1896. [CrossRef] [PubMed]

37. Lazo, G.R.; Stein, P.A.; Ludwig, R.A. A DNA transformation-competent Arabidopsis genomic library in Agrobacterium. BioTechnology 1991, 9, 963-967. [CrossRef] [PubMed]

38. Xiong, Z.; Kim, K.H.; Kendall, T.L.; Lommel, S.A. Synthesis of the putative red clover necrotic mosaic virus RNA polymerase by ribosomal frameshifting in vitro. Virology 1993, 193, 213-221. [CrossRef] [PubMed]

39. Hajdukiewicz, P.; Svab, Z.; and Maliga, P. The small, versatile pPZP family of Agrobacterium binary vectors for plant transformation. Plant Mol. Biol. 1994, 25, 989-994. [CrossRef]

40. Carrington, J.C.; Heaton, L.A.; Zuidema, D.; Hillman, B.I.; Morris, T.J. The genome structure of turnip crinkle virus. Virology 1989, 170, 219-226. [CrossRef]

41. Hearne, P.Q.; Knorr, D.A.; Hillman, B.I.; Morris, T.J. The complete genome structure and synthesis of infectious RNA from clones of Tomato bushy stunt virus. Virology 1990, 177, 141-151. [CrossRef]

42. Kumar, S.; Stecher, G.; Tamura, K. MEGA7: Molecular evolutionary genetics analysis version 7.0 for bigger datasets. Mol. Biol. Evol. 2016, 33, 1870-1874. [CrossRef]

43. Angel, C.A.; Hsieh, Y.-C.; Schoelz, J.E. Comparative analysis of the capacity of tombusvirus P22 and P119 proteins to function as avirulence determinants in Nicotiana species. Mol. Plant-Microbe Interact. 2011, 24, 91-99. [CrossRef]

44. Scheets, K. Analysis of gene functions in maize chlorotic mottle virus. Virus Res. 2016, 222, 71-79. [CrossRef]

45. Palanichelvam, K.; Cole, A.B.; Shababi, M.; Schoelz, J.E. Agroinfiltration of cauliflower mosaic virus gene VI elicits hypersensitive response in Nicotiana species. In Mol. Plant-Microbe-Interact.; 2000; Volume 13, pp. 1275-1279.

46. Abbink, T.E.M.; Tjernberg, P.A.; Bol, J.F.; Linthorst, H.J.M. Tobacco mosaic virus helicase domain induces necrosis in N-gene-carrying tobacco in the absence of virus replication. Mol. Plant-Microbe. Interact. 1998, 11, 1242-1246. [CrossRef]

47. Erickson, F.; Holzberg, S.; Calderon-Urrea, A.; Handley, V.; Axtell, M.; Corr, C.; Baker, B. The helicase domain of the TMV replicase proteins induces the $N$-mediated defense response in tobacco. Plant J. 1999, 18, 67-75. [CrossRef] [PubMed]

48. Huang, C.; Liu, Y.; Yu, H.; Yuan, C.; Zeng, J.; Zhao, L.; Tong, Z.; Tao, X. Non-structural protein NSm of tomato spotted wilt virus is an avirulence factor recognized by resistance genes of tobacco and tomato via different elicitor active sites. Viruses 2018, 10, 660. [CrossRef] [PubMed]

49. Daubert, S.D.; Schoelz, J.E.; Li, D.; Shepherd, R.J. Expression of disease symptoms in cauliflower mosaic virus genomic hybrids. J. Mol. Appl. Genet. 1984, 2, 537-547. [PubMed]

50. Schoelz, J.E.; Shepherd, R.J.; Daubert, S.D. Region VI of cauliflower mosaic virus encodes a host range determinant. Mol. Cell. Biol. 1986, 6, 2632-2637. [CrossRef] [PubMed] 
51. Scholthof, H.B.; Scholthof, K.-B.G.; Jackson, A.O. Identification of tomato bushy stunt virus host-specific symptom determinants by expression of individual genes from a potato virus X vector. Plant Cell 1995, 7, 1157-1172.

52. Wang, K.; Empleo, R.; Nguyen, T.T.V.; Moffett, P.; Sacco, M.A. Elicitation of hypersensitive responses in Nicotiana glutinosa by the suppressor of RNA silencing protein P0 from poleroviruses. Mol. Plant Pathol. 2015, 16, 435-448. [CrossRef]

53. Padgett, H.S.; Beachy, R.N. Analyis of a tobacco mosaic virus strain capable of overcoming $N$ gene-mediated resistance. Plant Cell 1993, 5, 577-586.

54. deRonde, D.; Butterbach, P.; Lohuis, D.; Hedil, M.; van Lent, J.W.M.; Kormelink, R. Tsw gene-based resistance is trigered by a functional RNA silencing suppressor portein of the tomato spotted wilt virus. Mol. Plant Pathol. 2013, 14, 405-415. [CrossRef]

55. Bendahmane, A.; Kanyuka, K.; Baulcombe, D.C. The $R x$ gene from potato controls separate virus resistance and cell death responses. Plant Cell 1999, 11, 781-791. [CrossRef]

56. Vleeshouwers, V.G.A.A.; Rietman, H.; Krenek, P.; Champouret, N.; Young, C.; Oh, S.-K.; Wang, M.; Bouwmeester, K.; Vosman, B.; Visser, R.G.F.; et al. Effector genomics accelerates discovry and funcational profiling of potato disease resistance and Phytophthora infestans avirulence genes. PLoS ONE 2008. [CrossRef] [PubMed]

57. Morales, F.; Castano, M.; Calvert, L.; Arroyave, J.A. Furcraea necrotic streak virus: An apparent new member of the dianthovirus group. J. Phytopathol. 1992, 134, 247-254. [CrossRef]

58. Powers, J.G.; Sit, T.L.; Heinsohn, C.; Gerorge, C.G.; Kim, K.-H.; Lommel, S.A. The red clover necrotic mosaic virus RNA-2 encoded movement protein is a second suppressor of RNA silencing. Virology 2008, 381, 277-286. [CrossRef] [PubMed]

59. Takeda, A.; Tsukuda, M.; Mizumoto, H.; Okamoto, K.; Kaido, M.; Mise, K.; Okuno, T. A plant RNA virus suppresses RNA silencing through viral RNA replication. EMBO J. 2005, 24, 3147-3157. [CrossRef] [PubMed]

60. Miras, M.; Sepere, R.N.; Kraft, J.J.; Miller, W.A.; Aradna, M.A.; Truniger, V. Interfamilial recombination between viruses led to acquistion of a novel translation-enhancing RNA element that allows resistance breaking. New Phytol. 2014, 202, 233-246. [CrossRef]

61. Ren, T.; Qu, F.; Morris, T.J. HRT gene function requires interaction between a NAC protein and viral capsid protein to confer resistance to turnip crinkle virus. Plant Cell 2000, 12, 1917-1925. [CrossRef] [PubMed]

62. Nakahara, K.S.; Masuta, C. Interaction between viral RNA silencing suppressors and host factors in plant immunity. Curr. Opin. Plant Biol. 2014, 20, 88-95. [CrossRef]

63. Pumplin, N.; Voinnet, O. RNA silencing suppression by plant pathogens: Defense, counter-defense and counter-counter-defense. Nat. Rev. Microbiol. 2013, 11, 745-759. [CrossRef]

64. Sit, S.L.; Lommel, S.A. Tombusviridae. In eLS; John Wiley and Sons, Ltd: Chichester, UK, 2015. [CrossRef]

65. Culver, J.N. Tobacco mosaic virus assembly and disassembly: Determinants in pathogenicity and resistance. Annu. Rev. Phytopathol. 2002, 40, 287-308. [CrossRef]

66. Toedt, J.M.; Braswell, E.H.; Schuster, T.M.; Yphantis, D.A.; Taraporewala, Z.F.; Culver, J.N. Biophysical characterization of a designed TMV coat protein mutant, R46G, that elicits a moderate hypersensitive response in Nicotiana sylvestris. Protein Sci. 1999, 8, 261-270. [CrossRef]

67. Doroszewska, T.; Depta, A. Resistance of wild Nicotiana species to different PVY isolates. Phytopathologia 2011, 59, 9-24.

68. Laskowska, D.; Doroszewska, T.; Depta, A.; Kursa, K.; Olszak-Przybyś, H.; Czubacka, A. A survey of Nicotiana germplasm for resistance to Tomato spotted wilt virus (TSWV). Euphytica 2013, 193, 207. [CrossRef]

69. Yuan, X.; Yan, C.; Wu, Z.; Ren, F.; Zhang, H.; Baker, B.; Chen, J.; Kuang, H. Frequent gain and loss of resistance against tobacco mosaic virus in Nicotiana species. Mol. Plant 2015, 8, 1813-1815. [CrossRef] [PubMed]

70. Balaji, B.; Cawly, J.; Angel, C.; Zhang, Z.; Palanichelvam, K.; Cole, A.; Schoelz, J. Silencing of the $N$ family of resistance genes in Nicotiana edwardsonii compromises the hypersensitive response to tombusviruses. Mol. Plant-Microbe Interact. 2007, 20, 1262-1270. [CrossRef] [PubMed]

(C) 2019 by the authors. Licensee MDPI, Basel, Switzerland. This article is an open access article distributed under the terms and conditions of the Creative Commons Attribution (CC BY) license (http://creativecommons.org/licenses/by/4.0/). 